\title{
Assessing Impacts of COVID-19 on Agricultural Production and Food Systems in the World and in Turkey
}

\section{COVID-19'un Dünyada ve Türkiye'de Tarımsal Üretim ve Glda Sistemlerine Etkisinin Değerlendirilmesi}

\author{
Rahmiye Figen CEYLAN ${ }^{\mathrm{a}^{*}}$, Burhan ÖZKAN ${ }^{\mathrm{b}}$

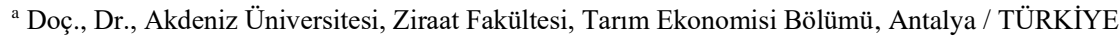 \\ ORCID: 0000-0003-0459-7521.

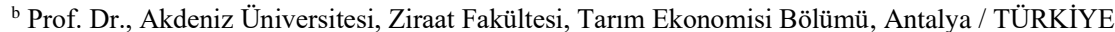 \\ ORCID: 0000-0002-9799-654X.
}

\begin{tabular}{|c|c|}
\hline M A K A L E B İ L G İ S İ & Ö Z \\
\hline $\begin{array}{l}\text { Anahtar Kelimeler: } \\
\text { COVID-19 } \\
\text { Tarım } \\
\text { Gıda sistemi } \\
\text { Talep ve arz } \\
\text { Gıda güvenliği ve güvencesi }\end{array}$ & 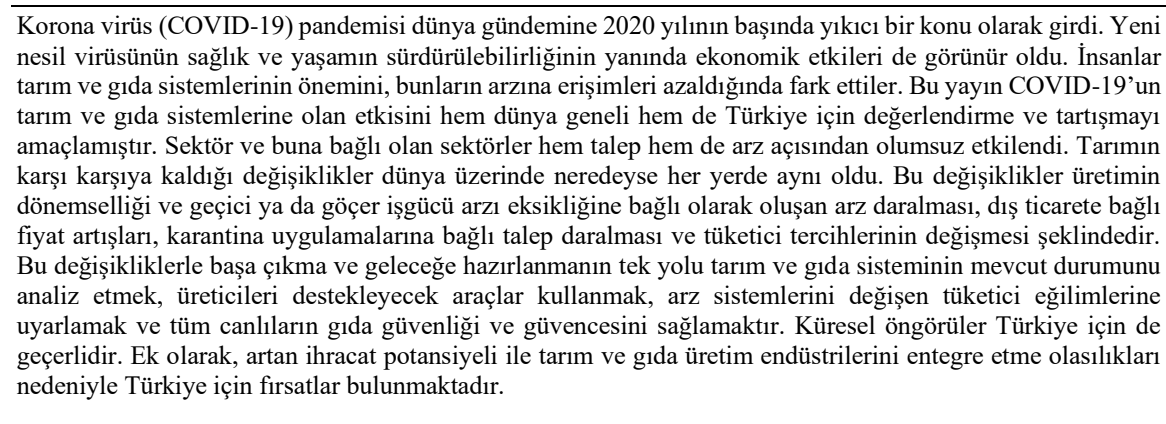 \\
\hline A R T ICLE INFO & A B S T R A C T \\
\hline $\begin{array}{l}\text { Article History: } \\
\text { Received August 24, } 2020 \\
\text { Accepted October 12, } 2020 \\
\text { Keywords: } \\
\text { COVID-19 } \\
\text { Agriculture } \\
\text { Food system } \\
\text { Demand and supply } \\
\text { Food security and safety }\end{array}$ & $\begin{array}{l}\text { The coronavirus (COVID-19) pandemic entered the world's agenda as a devastating health issue at the } \\
\text { beginning of 2020. In addition to health and survival related effects of the novel virus, economic effects had } \\
\text { shown up as well. People realised the importance of agriculture and the food system when accessibility to those } \\
\text { supplies diminished. This paper aimed to assess and discuss the impacts of COVID-19 on agricultural } \\
\text { production and food supply systems both globally and in Turkey. The sector and correlated sectors have been } \\
\text { affected negatively both in terms of demand and supply. The challenges agriculture has faced are similar } \\
\text { everywhere around the globe. These challenges are reducing supplies due to seasonality of production and lack } \\
\text { of seasonal or migrant labour, rising prices due to reduced international trade, reducing demand due to } \\
\text { lockdown implementations and changing attitudes of consumers. The only way to cope with these challenges } \\
\text { and prepare for the future is to analyse the current situation of agriculture and food system, to utilise tools to } \\
\text { empower suppliers, to adapt supply systems respecting changing customer attitudes and to assure food security } \\
\text { and safety of livelihoods. This global projection is also valid for Turkey. In addition, there are opportunities } \\
\text { for Turkish agriculture regarding rising export potential and possibilities to integrate agriculture and food } \\
\text { production industries. }\end{array}$ \\
\hline
\end{tabular}

\footnotetext{
* Sorumlu yazar/Corresponding author.

e-posta: ceylan.figen@gmail.com
} 


\section{EXTENDED ABSTRACT}

Yeni nesil Korona virüs ya da Dünya Sağlık Örgütü’nün kısaltmasıyla COVID-19 dünya gündemine dünyanın tamamen hazırlıksız olduğu bir dönemde aniden girdi. 2020 yılbaşından itibaren virüsün varlığı konuşulurken, virüsün dünya genelinde bir tehdit olarak tanımlanması 2020 Mart ayında gerçekleşti. Yılın yarısına kadar geçen dönemde virüs dünyanın hemen her yerinde hayat kayıplarına yol açtığı gibi, bu makale çalışması sırasında henüz yayılma ve ölümcül etki anlamında tam olarak kontrol altına alınamamıştı. Kısa bir süre içinde virüsün yaşam kayıpları ve sağlık sistemlerine etkilerinin yanında ekonomik etkilerinin üzerinde durulmaya başlanmıştır. Milli gelir, işsizlik, fiyatlar genel düzeyi gibi makroekonomik etkilerin yanı sıra, sektörel düzeyde etkilerin de değerlendirilmesi kaçınılmaz hale gelmiştir.

Hem hayatın hem de ekonominin sürdürülebilirliği için yaşamsal öneme sahip olan tarım sektörü makroekonomik göstergelerden etkilendiği gibi bu göstergeleri etkileyen değişikliklerle karşı karşıya kalmıştır. Tarımsal üretim ve bağlı gıda endüstrisi hem arz ve talep yönünden süreçten etkilenmekte hem de süreci etkilemektedir. Bu bakış açısıyla, bu çalışma kapsamında tarım ve gıda sektörlerinin COVID-19 pandemisi nedeniyle karşı karşıya kaldığı değişimler dünya örnekleri göz önünde bulundurularak değerlendirilmiştir. Çalışmada farklı literatür kaynaklarının ortaya çıkardığı bulguların tartışılmasının ardından, pandeminin Türkiye tarım sektörüne etkileri değerlendirilmiş ve Türk tarım ve gıda endüstrinin güçlü ve zayıf yanları ile karşı karşıya kaldığı fırsat ve tehditler ortaya koyulmuştur. Tarım ve gıda sektörleri üzerinde oluşan etkilerin değerlendirilme ihtiyacı ve bu etkilere müdahale gerekliliği pek çok sektörden daha öncelikli olarak görülebilir. Bunun temel nedenleri, bu sektörün çıktılarının yaşamın devamlılığ için vazgeçilmez olması ve faaliyetlerinin zamana bağlılı̆̆ nedeniyle durdurulma ya da ertelenmesinin mümkün olmamasıdır. Hastalığın yaygınlaşması ile ortaya çıkan ilk etki özellikle bitkisel üretimde hasat zamanlarında yaşanan aksaklıklar olmuştur. Pek çok ülkede hasat zamanında işgücü erişimi ciddi ölçüde azaldığı gibi, karantina ve hareketlilik kısıtları ürünlerin tarladan sofraya ulaşmasında sıkıntılar yaratmıştır. Araştırmalar hasat ertelemelerinin başta Akdeniz ülkeleri olmak üzere pek çok ülkede ürün kayıplarına yol açtığını göstermiştir. Ürün kayıpları sadece çiftçi gelirlerinin düşmesi ya da sektörün milli gelire katkısının azalması anlamına gelmemiş, aynı zamanda hem tarımsal işgücünün gelir kaybı yaşaması hem de gıda güvenliği ile ilgili sorunlarla karşılaşılmasına sebep olmuştur. Arz daralması ile birlikte hareket kısıtlamalarına dayalı azalan ticaret olanakları tüketicinin karşılaştığı fiyatların da yükselmesine sebep olmuştur. Bu sürecin bir başka etkisi yüz yüze alışverişlerin azalması ve bozulabilir tarım ürünlerinde dahi internet üzerinden alışveriş istekliliğinin artması ve başta perakende zincirleri olmak üzere pek çok tedarikçinin sistemlerinde çevrimiçi alışveriş olanaklarını artırmasına yol açmıştır. Dolayısıyla, süreç hemen hemen tüm ülkelerde daralan arza karşılık, değişen satın alma ve tedarik sistemleri ve bunların uzun vade etkilerini değerlendirmeye odaklanmalıdır.

$\mathrm{Bu}$ sürecin Türkiye açısından değerlendirilmesinde önemli hususlar, Türkiye'nin sahip olduğu kaynaklar kadar sektörün iç ve dış arz açısından konumu ile ilişkilidir. Türk tarımının iç arz yeterliliğine katkı sağlayabilecek en güçlü taraflarından birisi, başka açılardan güçsüzlük olarak değerlendirilen, aile çiftçiliği ve pek çok ürün açısından harici işgücü bağımlılığının göreceli olarak az olmasıdır. Ayrıca süreç içerisinde perakende zincirleri kadar özellikle kentli nüfusun internet üzerinden ürün tedarikine adaptasyon hızı ve düzeyi iç piyasa yeterliliğini koruyacak güçlü özelliklerden birisidir. Ancak üretimin sürdürülebilirliğine daha az olumsuz etki yapan küçük üretici yapısı bu sistem değişimine kolay adapte olamamaktadır ve üreticiler hem iç piyasaya hem de ithalat yoluyla edinilen girdilere erişim açısından sıkıntı yaşamaktadır. Sektörün avantajları ise kamu ve sivil toplum eliyle yürütülen danışmanlık ve destek hizmetleri ile tedarik zincirinin desteklenmesidir. Bu destek yapısı işletmelerde hijyen uygulamalarının kısa sürede yaygınlaştırılmasına ve işletmeler ile endüstri arasında bağların sürdürülmesine katkı sağlayabilecek güçtedir. Ayrıca, Türkiye tarım ve gıda sektörleri hareket kısıtlarının gevşetilmesi ile Temmuz 2020 itibariyle turizm sektöründen gelen talep artışı ile karşı karşıya kalmıştır ve bu talep artışının faaliyetlerin sürdürülebilirliğine katkı sağlaması beklenmektedir. Ancak, bu süreç girdi bağımlılığı ve profesyonel olmayan nakliye ve tedarik sistemlerine müdahale gereksinimini de ortaya çıkarmıştır. 


\section{Introduction}

The world has faced a devastating crisis with the COVID-19 outbreak. It has affected livelihoods and health care systems throughout the world. This outbreak has threatened the survival of many people. As it was named as a pandemic by the WHO in March 2020, the fear expanded from health issues towards economics. Because survival means not only avoiding death, but also meeting basic needs. Accordingly, in addition to the need to find solutions to the spread and mortality of the virus, there is the need to cure its economic consequences. When the economic effects of epidemics are considered, it is inevitable to focus on agriculture and the food system through its effects on demand and supply.

Agriculture is essential for life and the food system is essential for today's modern society. It is not possible to shut down these operations without devastating consequences. Therefore, the effects of the novel Coronavirus - COVID-19 on agriculture and food systems need to be assessed. Recently, some research has been conducted on direct and potential future effects of the pandemic. Accordingly, this paper focuses on assessment of COVID-19 effects on agriculture and food system with reference to recent research. In addition to reviewing the existing situation globally, this paper assesses the agriculture and food system in terms of the strengths, weaknesses, opportunities and threats for Turkey with reference to COVID-19. Accordingly, the analysis suggests potential ways to cope with COVID-19 and future natural or man-made disasters.

\section{Effects of COVID-19 on agriculture and the food system}

Ultimately, the COVID-19 effects on agriculture and the food system need to be considered through supply and demand dimensions. Direct effects resided on the nature of agricultural practices despite the lockdowns in many countries. When you stop people from moving, many economic activities stop as well. However, agricultural practices cannot be stopped easily. For instance, plantation, harvest, transportation and marketing of perishable products must continue. Maintaining delivery of inputs and outputs of the food industry is necessary. Therefore, agricultural production and the food system should be evaluated together.

The direct impact on agriculture first appeared with crop harvest, specifically for perishable crops. The crops were ripe and perishable, but the food system was disrupted, and those products could not reach the final consumer. Initially, the pandemic affected Mediterranean climate countries in Europe. These countries have abundant agricultural capacity and their economies depend on agriculture. The outbreak posed a serious threat to food security as these countries were main suppliers of the old continents and even overseas.

Considering harvest problems, lockdown measures led to loss of labour. In the beginning, at least for the countries in the northern hemisphere, this was not a huge problem. However, the harvest of vegetables and fruits that are mostly perishable had declined due to labour shortages (Stephens et al., 2020; Phillipson et al., 2020). Research conducted for southern Italy showed the importance of temporary labour for farm-level operations. The results indicated that farms more dependent on family labour seemed to be more resilient than those depending on external labour (Cortignani et al., 2020). Effects of labour mobility restrictions were not limited to southern Europe. For instance, the farms heavily dependent on seasonal labour in the UK, most of which were involved in animal breeding, were seriously affected by the lockdown (Seleiman et al., 2020). These restrictions not only caused productivity and marketability loss to farm operators but also led to an income loss for those workers. For India, this labour unavailability affected the harvest of many agricultural products like watermelons (Saha \& Bhattacharya, 2020). 
Therefore, delayed or disrupted harvests both led to a loss in farm or labour income and they also presented problems for food security (Seleiman et al., 2020). For example, while the agricultural labour contraction expected for Indonesia in 2020 was 4,87 \%, the expected loss in domestic agricultural supply was 6,20\% (Amanta \& Aprilianti, 2020). This signifies that the loss in value of products is more than the loss of labour income. This will affect farm income levels in return with reduced supplies and rising prices attached to declining household income. For instance, migrants account for $70 \%$ of the labour used in wheat cultivation in Pakistan. The pandemic led to a major loss in the harvest and resulted in declining supply and rising prices. The decline in national supply meant rising demand for imports (Khan et al., 2020). But will it be possible to increase or maintain agricultural trade in the near future?

Food supplies relying on international transactions would face problems too. The same problems with labour mobility, transportation problems, and rising prices will appear for exporting countries. Checking out the situation of farmers, the disease led to both inability to transfer products and to acquire ingredients as chemicals or feeds (Seleiman et al., 2020; Abouhatab, et al., 2020). There appear security concerns, both productive security and food security. Even if family farm level resilience seems to continue despite restrictions, the farmers in many countries could reach neither input nor sales markets. There have been exemptions for transportation of pesticides, seeds or final products as announced in India for instance (Chatterjee, 2020). However, the routes had changed and timely delivery became problematic for perishable vegetables and fruits. The linkages between producer and consumer markets were disrupted. In addition to marketing and logistic problems, farmers have become indecisive with regards to the maintenance of production and harvest activities. This is valid for animal production as well. Zhang (2020) conducted a survey with Indian breeders and found that $38.5 \%$ of their problems from the COVID-19 pandemic were logistics. The importance of the problems related to logistics for all agricultural enterprises had appeared as 35,6\%, signifying higher devastation for animal breeding activities.

Efficiency of subsistence farms fell as well. Even if the production and harvest remained under control, the marketing uncertainties had entirely affected the farmers. In many districts, where open bazaars, farmer markets or street vending is maintained, the loss of farmer income became inevitable especially for fresh and perishable products as it was the case for Chile (Kanter \& Boza, 2020).

Another significant problem appeared for stocked or storable products due to integration of sectors. Countries with excess supply or efficient agricultural production capacity meet the demand of the service sectors. Not surprisingly, these sectors were shut as well. The demand of the tourism sector, especially in the Mediterranean and European countries, shrunk desperately. Even six months after COVID-19, there seems no promising sign for rising tourism activities in a sustainable way. Most countries declared that they would maintain their border closures, including airspace restrictions, as of June 2020. Even though hosting countries announced that they are opening up, many countries declared that they would not allow travel for touristic purposes to many destinations. Besides, self-security concerns have demotivated people for international touristic expenditures, even if they have adequate endowments. UNWTO estimated a 20-30 \% decline in international travel for 2020 in comparison to 2019 (Gössling et al., 2020). Thus, tourism is not a significant customer for agriculture and agro-food industries at least in 2020 .

Institutional demand for agriculture and food services includes much more than hotels and tourism. Lockdowns have included restaurants, workplace cafeterias, schools, and other important customers. Even if many countries enabled these services under social distancing rules, consumers have changed their perceptions and preferences. Accordingly, people's use of outdoor catering and entertainment activities, including visits to shopping malls, had slowed 
down significantly (Ceylan \& Ozkan, 2020). Stay at home orders have been extended and the only growing services branch is courier and delivery services (Stephens et al., 2020). These changing attitudes have led to decreasing demand for fresh fruits and vegetables and meat products as more people eat and cook at home, foregoing cafés and restaurants. Accordingly, following service providers and employees in the services sector, agricultural and food product suppliers were affected negatively from this attitude change. Global food prices are affected seriously by the falling hotel and restaurant demand, resulting in an estimated $20 \%$ reduction in agricultural prices globally (Nicola et al., 2020).

Major exporters of cereals and grains such as Russia and Romania for wheat, Thailand, Cambodia, and India for rice, imposed trade restrictions for national food security (Zurayk, 2020). By May 2020, 35 countries imposed export restrictions (Martin et al., 2020). Vietnam, the third biggest rice exporter, temporarily cancelled its export contracts by the end of March 2020 and this condition surely affected both prices of rice and food security and safety of rice importer countries (Gulcubuk, 2020). Respecting soybean trade, the USA export market did not recover completely even after the trade deal made with China by January 2020 (Mallory, 2020). While many countries intended to reduce import barriers, the main suppliers did not want to export due to food security and transportation concerns. Here food security means reaching an adequate amount of product required to survive, while food safety means having the ability to reach good quality and healthy products. Importers of these main staples have been facing both security and safety problems. These sorts of restrictions led to rising prices in importing countries as well. Yet, grains can be stored, so consumption can take place out of storage and new grain stored by exporters can reduce future international prices.

Domestic market conditions affected the international trade of storable agricultural and food products. Therefore, domestic and international agricultural prices in many countries got affected. The FAO Food Price Index for the first six months of 2020 was demonstrated in Figure 1 (FAO, 2020).

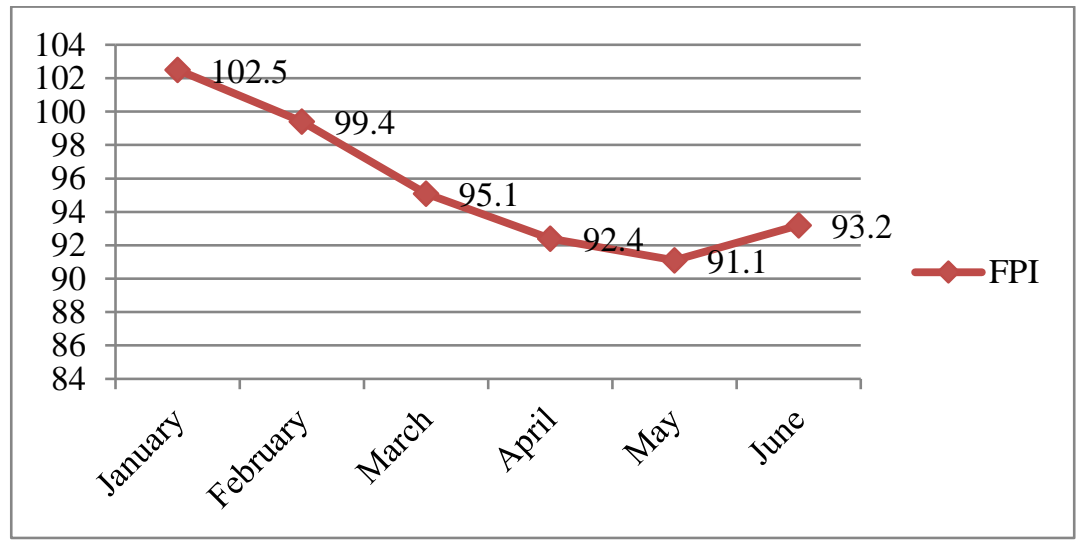

Figure 1: FAO Food Price Index (monthly)

The average price index declined from January until May due to falling demand attached to COVID-19 (Eren, 2020). Prices began to recover in June, which has been considered as an indicator of rising supplies and changing market conditions (FAO, 2020). The recovery was visible in dairy products, vegetable oils and sugar, while the stagnation in meat products and cereals continued. These price changes are related to various trade restrictions and COVID-19 conditions in the main supplier countries. Decision-making process of both producers and consumers has been disrupted within this duration.

Consumer attitudes have changed drastically. Online orders by consumers for both storable and packaged food products and fresh products have become more popular, among 
particularly people having internet access. A household-level analysis made for China indicated an overall reduction of daily offline consumption by $32 \%$ (Chen et al., 2020), while online spending had risen.

Chang and Meyerhoefer (2020) analysed changing purchase and consumption behaviour in Taiwan. They found that an additional confirmed COVID-19 case led to a 249 NT\$ $(8,46 \text { US\$ })^{1}$ rise in sales revenue for online food sellers. An additional COVID-19 case meant a $5,7 \%$ rise in revenue and a $4,9 \%$ rise in the number of online customers.

Online food orders and online delivery have been rising for Germany as well, where the digital transition had been limited for food shopping earlier (Dannenberg et al., 2020). Researchers found that online grocery purchases increased but with a limited speed when compared with storable products. Share of Canadian households that make online grocery purchases rose from 1,5\% to $9 \%$ by March 2020 (Richards \& Rickard, 2020; Charlebois, 2020).

Consumers not only shifted to online purchases and delivery services, but also reduced their outdoor consumption leading to a rising volume for retail grocers, specifically in Europe and North America. Even after panic buying emerged in March 2020, the tendency to shop at neighbourhood supermarkets has risen with attention to social distancing rules. Some restaurants and cafes turned their attention to delivering refrigerated or frozen foods directly to consumers, as seen in the UK and USA (Nicola et al., 2020). These deliveries, along with curb side sales and take-out, compensated for some losses (Lusk, 2020).

Controlling the spread of the Coronavirus is compulsory, but stopping additional hunger due to the virus is also a necessity. In 2019, 821 million people were food insecure, and about 149 million of them were classified as critically hungry. If COVID-19 cannot be controlled by the end of 2020, the expected number of death per day globally is 12.000 (OXFAM, 2020). Yet, the World Food Programme estimated that the number of people that would face acute food insecurity would be 265 million; double of the pre-epidemic estimates (Montalvo \& Van de Velde). This means that food safety and food security problems may override due to COVID19. These numbers suggest that food supply sustainability and resilience must be planned. The hunger risk for Yemen, Democratic Republic of Congo (DRC) Afghanistan, Venezuela, the West African Sahel, Ethiopia, Sudan, South Sudan, Syria, and Haiti is higher than other countries.

Food insecurity is a case for many parts of the world, but it is more severe in African countries. Nigerian farmers and households have been experiencing problems in supplydemand linkages for years. Markets have not delivered physical inputs and labour necessary for farmers within the pandemic process. Accordingly, households have been facing the lack of adequate reach to food (Otache, 2020).

Another important issue is the role of women in agriculture. Women play a vital role in rural areas in terms of contributing to agricultural development along with their household duties and non-agricultural activities. Women are involved in all stages of agriculture, from preparation of the land to tillage, hoeing, harvest, and post-harvest activities (like food processing, storage, and marketing of vegetables). Due to recent figures of the International Labour Organisation, female involvement in agricultural practices for 2019 was 25,41 \% globally (Anonymous, 2020a). The share was higher for overpopulated countries as Pakistan with $65,26 \%$ and India with 54,54\% (Malik \& Naeem, 2020). In addition, countries that heavily depend on rural economies experience higher female participation as well. The share of women in agriculture through Africa was $40 \%$, meaning more than $60 \%$ of employed

\footnotetext{
${ }^{1} 1 \mathrm{NT} \$=0,034$ US $\$(14.07 .2020)$
} 
women in Africa were involved in agricultural activities (O'Sullivan et al., 2014). Yet, the involvement rate for Turkey is slightly higher than the world average with $25,86 \%$ as of 2020 (Anonymous, 2020b).

Women generally have less access to and control over resources and there is much evidence that the lower status of women in agriculture hinders many development activities. On the other hand, it is more likely that rural women's economic and productive lives are affected more by the pandemic compared to men. As an instance, women in Sub-Sharan Africa, most of whom are involved in agricultural activities, lost their jobs or closed their businesses more than men (Copley, et al., 2020). Therefore, empowerment of rural women is rather important to mitigate the effects of Coronavirus. Focusing on extension activities and promoting cooperation of rural women would constitute supportive actions during the pandemic and afterwards.

Sustainable development and food security could be improved by breaking the barriers to inequity and providing equal opportunities to women in terms of access to capital, land, credit, and education. On the other hand, the climate crisis, such as droughts and floods, and less predictable weather patterns are increasing food insecurity in some countries, particularly in severe food insecurity hotspots.

It is important to note that both people and policymakers have recognised the importance of agricultural and food products in terms of demand and supply. This challenge observed up until now will continue to evolve, even after the pandemic. The remainder of this paper discusses the shifts and challenges in agriculture for Turkey.

\section{The impacts of Covid-19 on Turkish agriculture and food system}

The global restrictions and challenges discussed earlier are relevant to Turkey as well. Reaching internal and external input and output markets, lack of temporary labour, changing marketing channels and customer attitudes have been the main problems.

Considering Turkey's overall agricultural capacity, neither food safety nor food security problems are expected. Wheat is the main stable crop and it was already planted before the outbreak of the virus and it can also be harvested by machinery use. Therefore, labour inadequacy due to the lockdown and social distancing did not create a significant problem for wheat production and harvesting. Accordingly, available stocks and current wheat production are enough to meet domestic consumption.

However, despite its abundant resources and climatic availability, Turkey faced and will face price-related problems for all crops and livestock. Turkey is both an exporter and importer of wheat. Specifically, a significant share of the wheat used for flour and pasta production is imported. However, high-quality wheat exports and low-priced wheat imports were reduced due to trade restrictions. High-quality wheat stocks had to be directed to the flour and pasta making industry. While the income of wheat exporters is expected to decline, prices of flour and pasta produced domestically are expected to rise (Anonymous, 2020c). This is also related to export restrictions of many neighbouring countries which normally provide wheat to Turkey. The Russian Federation, Kazakhstan, and Algeria had already extended the duration of their export restrictions to secure their domestic requirements (Eren, 2020). Accordingly, price fluctuations are also expected to affect 2021 and the following years. Yet, this might be an opportunity as well. When countries like Italy and Spain, which heavily depend on grains for their daily nutrition and their situation concerning morbidity and mortality of COVID-19 are considered, their markets can be alternatives for Turkish grain exports. If domestic demand is met and if trade restrictions ease, Mediterranean countries can become export destinations for Turkish grains. 
Yet, the situation is different for fresh fruits and vegetables (FFVs) that are produced with specific timing and under special conditions. Production of FFVs mostly depend on seasonal/migrant labourers, so the lockdown and social distancing measures have affected all processes. Besides, due to legal enforcements, FFV producers depend heavily on imports of seeds, herbicides and pesticides. The reduction in trade of these inputs will most likely affect the quality and quantity of FFV crops (Atabas, 2020).

There has been no permanent lockdown in Turkey. However, temporary lockdowns have affected district bazaars. The income of family farmers got affected negatively since they supply their products to these bazaars.

Besides, shipment of products to other provinces in the country during mobility restrictions and transportation controls led to negative supply shifts and posed problems for consumers due to high prices and unavailability of products. This resulted in income losses for farmers and domestic traders. While farm prices had declined and stocks increased during March and April 2020, lock-downs and health security concerns encouraged households to avoid shopping from fresh markets (Duran \& Acar, 2020).

When the attitudes of consumers were overviewed, similarities to the global challenges were observed. Visits for outdoor catering services were reduced and mostly replaced with house consumption. Retail channels, like supermarkets, secured their place during and after the stockpiling process and many traditional retailers adapted their systems to online delivery. Many chain stores, including discount markets, opened online delivery systems (Toktas, 2020). The online shopping tendency is expected to rise, which has ramifications for developing a services branch, while a reduction in offline purchases might lead to unemployment, as has been observed globally (Ceylan et al., 2020; Pillipson et al., 2020).

The transition from offline to online purchasing has been accepted for a range of activities. A significant example of this challenge is from Turkey. A special artichoke festival has been held in Izmir province of Turkey for years with 3 million national and international visitors on average per year. After the festival was cancelled for 2020, Urla Women's Cooperative received significant numbers of internet orders (Keyder et al., 2020). These webbased purchases contributed to the sustainability of the artichoke festival. This is an example of potential empowerment for rural women and cooperatives.

The restrictions were not limited to national markets; they also included exports due to restrictions which will likely remain for some time. The lack of export markets for fresh products also led to an excess supply in the production centres, mostly in the Mediterranean and Aegean coasts of Turkey, and declining prices. A significant problem for Turkish agriculture due to COVID-19 is related to seasonal production. This seasonality and fluctuating labour constitute problems not only for agriculture and the food supply system, but also for the sustainability of rural economies and prevention of overpopulation in economically active cities due to migration of temporary labourers. Many precautionary actions were discussed and instituted in agriculture-dependent provinces of Turkey between April 25, 2020 and May 15, 2020. It was decided to keep temporary agricultural labourers in the agricultural districts with provision of phytosanitary precautions. Tents were organized for social distancing, sanitation material was provided for free, and registration and monitoring of labourers' household members were considered as primary actions (Zirh, et al., 2020). Also, farmers were asked to receive specific permissions from public institutes to maintain agricultural practices.

The above-mentioned situations and expectations can be summarised as strengths, weaknesses, opportunities and threats posed by Turkish agriculture (Table1). 
Table 1: SWOT Analysis of Turkish agriculture concerning for Covid-19

\section{Strengths}

- Availability of stocks of durable agricultural products reduces safety and security risks.

- The annual harvest of most agricultural products is highly mechanized with lower requirement of external labour.

- The fast transition of retail markets and food industries to online order and delivery services is promising for food security of the society.

- Strong and developed courier services contribute to the digital transition.

- Majority of the farms are family farms and therefore they do not need external workers.

\section{Weaknesses}

- Rising FFVs supplies and reduced exports seem to create problems for small scale producers.

- Lack of imported input deliveries and problems in transportation have led to rising domestic market prices.

- Risks regarding using more family labour and rising non-paid employment contribute to declining farm incomes.

- Downsizing in tourism and out of home catering services creates excess supply of many domestically sold products.

- Weak attachment of small agricultural enterprises to internet orders is risky for those suppliers.

\section{Opportunities}

- Family farm resilience in small and medium scaled FFVs production and use of family labour may reduce relative variable costs and prices.

- Rising export potential for high quality storable grains to countries where domestic supplies are disrupted is an opportunity for survival and sustainability.

- Possible integration of FFVs suppliers and food industry via supportive actions of civil society and public authorities will lead controlling the disease process and contribute to empowerment in the sector.

- Public level dedication to improve phytosanitary practices in agricultural enterprises is significant and should be utilised efficiently on farm level.

- Acceptance of phytosanitary requirements and social distancing measures by medium and large scaled enterprises is promising.

- Rising touristic activities have been observed by July 2020 that induced demand from agriculture.

- Sectoral cooperation and availability of consultancy services support sustainability.

\section{Threats}

- Continuation and expansion of international trade restrictions might specifically affect FFVs exports.

- Underdeveloped domestic input market for seeds, pesticides and herbicides poses problems for maintenance of agricultural production.

- Unavailability of seasonal labourers for FFVs harvest and animal production activities make labour costly.

- Dependence on seasonal labour in many activities and cyclical income and consumption loss of unemployed labourers may increase the negativity in agricultural production.

- Rising transportation costs due to local restrictions and social distancing rules contribute to rising prices. 
- Opportunities to install own transportation lines and rising mechanisation with cooperation and availability of credit access may be contributory.

- Adaptation of retail chains to online delivery systems and rising contact with farmers should be assured.

- Openness of rural women for integration to society should be activated via civil society and public guidance.

\section{Conclusions and Suggestions}

The world will be better off by learning to cope with the current Coronavirus pandemic and potential epidemics respecting all type of effects. What we have considered so far is the importance of human survival with all aspects and just after remaining alive, sustaining life takes place. Therefore, the world was challenged by the Coronavirus with regards to agricultural sustainability, food security and food safety. In this paper, we have explained some effects of the COVID-19 pandemic on agricultural and food systems both around the world and in Turkey. The problems and possible measurements to be taken were assessed and demonstrated briefly.

The effects of the pandemic on Turkish agriculture are valid for other countries, where agriculture is important in terms of economic contribution. Many developing and Mediterranean countries with similar agricultural endowments and social structures should consider empowerment of agricultural production, marketing, and trade lines. Within this context, some specific measures should be considered, planned, and implemented.

The most important action is assuring security of food production and supply systems. Taking precautionary actions is essential for agricultural production but not sufficient. Perishable agricultural production is conducted by small and medium scaled enterprises in Turkey and many other countries. This challenges the logistics for inputs and final outputs. Accordingly, cooperative actions are essential both for farmers and food industry representatives. Integration of the sector, which has been discussed on an academic and public level for decades, must become a priority for food security and safety.

The role of women farmers within this process and their empowerment is quite important to maintain farm-level operations and self-sufficiency of rural economies. If rural economies falter, non-employed agricultural workers will pose problems for urban economies as well due to domestic migration (OXFAM, 2020). Declining income of agricultural producers makes difficult to secure efficient food production. Income estimations show that farm income shrinkage is overwhelming. The World Bank estimated an almost $20 \%$ reduction in income transfers to low and middle-income countries due to the pandemic, which would mean a reduction of $\$ 100$ billion (Anonymous, 2020d). It implies that supporting agricultural production and related activities is crucial for all countries, but it is much more important for low-income countries.

Web-based services included in agricultural and food production and delivery have been changing the supply and demand dynamics. Empowerment of small-scale and rural enterprises should be inserted in the agenda of public authorities to capture the positive impacts of this evolution. Otherwise, the benefits of developing internet technology will be limited with an appreciation of large-scale enterprises. Accordingly, public authorities, shareholders and civil society should give high priority on this issue. 
Many countries, including Turkey, established credit channels both for consumers and small-scale enterprises. These credit channels should be utilised for security of input acquisition, development of local seeds and mechanisation of agricultural systems. Besides, not only the credit system but also some other supportive tools by public or civil society can be utilised for this purpose.

What has not been proposed earlier is potential opportunity respecting a new segmentation. Investment in production and sales of medicinal and aromatic plants may pose a significant opportunity. This potential is both related to metabolism empowerment and in-vivo studies that might be contributory to cope with COVID-19 and future epidemics (Sekeroglu \& Gezici, 2020).

Agriculture and the food systems are crucially important for all countries. The integration, sufficiency and development potential of agriculture and food system should be secured everywhere. The lessons learned from COVID-19 until now have showed some paths to all countries. Development, empowerment, support, and cooperation are crucial issues for agriculture and the food system now and these issues will likely be more important in the future.

\section{References}

Abouhatab, A., Boqvist, S., Gräslund, S., Hilbur, Y., Ortiz, R. (2020). SLUs global blog COVID-19 and food security reflections on Sweden's global contribution to Agenda 2030. DOI: 10.13140/RG.2.2.31590.86086. Retrieved 15.06.2020 http://blogg.slu.se/global-blog/2020/05/15/covid-19-and-food-security.

Amanta, F. \& Aprilianti, I. (2020). Indonesian food trade policy during Covid-19. CIPS: Center for Indonesian Policy Studies. Policy Brief: 1: 1-7. Retrieved 20.06.2020 https://www.cips-indonesia.org/post/policy-brief-indonesian-food-trade-policy-duringcovid-19.

Anonymous. (2020a). Employment in agriculture, female (\% of female employment) (modelled ILO estimate). The World Bank database Retrieved 25.09.2020 https://data.worldbank.org/indicator/sl.agr.empl.fe.zs

Anonymous. (2020b). Employment in agriculture, female (\% of female employment) (modelled ILO estimate). The World Bank database Retrieved 25.09.2020 https://data.worldbank.org/indicator/SL.AGR.EMPL.FE.ZS ?end=2019\&locations=TR \&start $=20$.

Anonymous. (2020c). Koronavirüsün (COVID-19) tarım ve gıda sektörüne etkileri raporu (Effects of Coronavirus (COVID-19) on agriculture and food sector). Bureau of Credit Registry - Joint Research Institute of Banking System - Report. pp: 26. Retrieved 10.07.2020

https://www.kkb.com.tr//Resources/ContentFile/KKB\%20Koronavir\%C3\%BCs\%C3 $\%$ BCn\%20Tar\%C4\%B1m\%20ve\%20G\%C4\%B1da\%20Sekt\%C3\%B6r\%C3\%BCne $\% 20$ Etkisi\%20Raporu_Nisan2020\%20(1).pdf.

Anonymous. (2020d). World Bank Press Release (22.04.2020). World Bank predicts sharpest decline of remittances in recent history. Retrieved 01.05.2020. https://www.worldbank.org/en/news/press-release/2020/04/22/world-bank-predictssharpest-decline-of-remittances-in-recent-history.

Atabas, O. (2020). Covid-19 Pandemisi gıda üretim ve tedarikini nasıl etkiler? (How does Covid-19 pandemic affect food production and supplies?). Institute of 21st Century, Special report. Retrieved 10.07.2020. https://21yyte.org/tr/ozel-raporlar/ozel-raporcovid-19-pandemisi-gida-uretim-ve-tedarikini-nasil-etkiler. 
Ceylan, RF. \& Ozkan, B. (2020). The economic effects of epidemics: From SARS and MERS to COVID-19. Research Journal in Advanced Humanities, 1(2), 22-29.

Ceylan, RF., Ozkan, B., Mulazimogulari, E. (2020). Historical evidence for economic effects of COVID-19. The European Journal of Health Economics, 21(6), 817-823.

Chang, HH. \& Meyerhoefer, C. (2020). COVID-19 and the demand for online food shopping services: Empirical evidence from Taiwan. NBER Working Paper No. 27427. June 2020

Charlebois, S. (2020). Why COVID-19 will change Canadian grocery industry forever: Expert. Retail Insider. Retrieved 01.07.2020. https://www.retailinsider.com.

Chatterjee, R. (2020). Indian agriculture and role of agricultural extension system to cope up with C0VID-19 crisis. Food and Scientific Reports. ISSN 2582-5437. Special Issue (1), $10-15$.

Chen, H., Qian, W., Wen, Q. (2020). The impact of the COVID-19 pandemic on consumption: Learning from high frequency transaction data. SSRN Working Paper. Retrieved 28.04.2020. https ://ssrn.com/abstract=35685 74 .

Copley, A., Decker, A., Delavelle, F., Goldstein, M., O'Sullivan, M., Papineni, S. (2020). COVID-19 pandemic through a gender lens. Africa Gender Policy Brief. World Bank, Washington, DC. World Bank. Retrieved 20.06.2020. https://openknowledge.worldbank.org/handle/10986/34016 License: CC BY 3.0 IGO.”

Cortignani, R., Carulli, G., Dono, G. (2020). COVID-19 and labour in agriculture: Economic and productive impacts in an agricultural area of the Mediterranean. Italian Journal of Agronomy, 15(2), 172-181. https://doi.org/10.4081/ija.2020.1653.

Dannenberg, P., Fuchs, M., Riedler, T., Wiedemann, C. (2020). Digital transition by Covid-19 pandemic? The German food online retail. Journal of Economic and Social Geography, 111(3): Special Issue: The geography of the Covid-19 pandemic, 543460. https://doi.org/10.1111/tesg.12453 DOI: 10.1007/s10198-020-01206-8.

Duran, MS. \& Acar, M. (2020). What a virus could do to the world: Macroeconomic effects of Covid-19 pandemic. International Journal of Social and Economic Sciences, 10(1), 5467.

Eren S. (2020). 'Koronavirüs salgını ve temel gıda piyasaları üzerindeki etkileri' (Coronovirus pandemic and effects on main food markets). Evaluation note of Economic Development $\quad$ Foundation. $\quad$ Accessed: 01.07 .2020 https://www.ikv.org.tr/images/files/covid19_ikv_selvi_eren_gida_piyasalar\%C4\%B1_ fiyat_endeksi_fao.pdf .

FAO (2020). FAO food price index. Retrieved 10.07.2020 http://www.fao.org/worldfoodsituation/foodpricesindex/en/.

Gössling, S., Scott, D., Hall, CM. (2020). Pandemics, tourism and global change: a rapid assessment of COVID-19. Journal of Sustainable Tourism. DOI: $10.1080 / 09669582.2020 .1758708$.

Gulcubuk, B. (2020). Future of agricultural policies after COVID-19. Report of Istanbul Political Research Institute (IstanPol). No:12 Retrieved 10.07.2020 https://en.istanpol.org/post/covid-19-sonras\%C4\%B1nda-tar\%C4\%B1mpolitikalar\%C4\%B1n\%C4\%B1n-gelece\%C4\%9Fi. 
Kanter, R. \& Boza, S. (2020). Strengthening local food systems in times of concomitant global crises: Reflections from Chile. American Journal of Public Health. 110(7), 971-973. DOI: 10.2105/AJPH.2020.305711.

Keyder, Ç., Bilgic, CN., Yenal, Z. (2020). COVID-19, Tarım ve Glda: Dünyada ve Türkiye'de neler yaşand, neler yaşanacak? (COVID-19: Agriculture and Food: What were experienced and what will be experienced in the world and in Turkey). Sarkac web platform. Retrieved 01.07.2020. https://sarkac.org/2020/07/covid-19-tarim-ve-gidadunyada-ve-turkiyede-neler-yasandi-neler-yasanacak/ .

Khan, KA., Ul Haq, MI., Khan, JM., Zahoor, M., Gohar, O, et al. (2020). Opinion on impact of covid-19 lockdown on agriculture. food security and livelihoods in Pakistan. International Journal of Agriculture and Biological Sciences, DOI: 10.13140/RG.2.2.22553.44641.

Lusk, J. (2020). Retail markets get a boost during COVID-19. Purdue Agricultural Economics Report. Special edition: COVID-19 impact on agriculture, 1-3. Retrieved 15.06.2020. https://ag.purdue.edu/agecon/Documents/PAER/PAER_April2020_final.pdf .

Malik, S. \& Naeem, K. (2020). Impact of COVID-19 Pandemic on women: Health, livelihoods $\&$ domestic violence. Policy review. Think Asia (Asian Development Bank). Retrieved 24.09.2020. https://think-asia.org/bitstream/handle/11540/11907/Covid19-impact-onwomen-_8-May-2020.pdf?sequence=1.

Mallory, M. (2020). Short-term effects of COVID-19 on U.S. soybean and wheat exports. Purdue Agricultural Economics Report. Special edition: COVID-19 impact on agriculture: $\quad 8-9 . \quad$ Retrieved 15.06 .2020$. https://ag.purdue.edu/agecon/Documents/PAER/PAER_April2020_final.pdf .

Martin, A., Markvhida, M., Hallegatte, S., Walsh, B. (2020). Socio-Economic impacts of COVID-19 on household consumption and poverty. Cornell University (the USA). Retrieved 25.06.2020. https://arxiv.org/abs/2005.05945.

Montalvao, J. \& Van de Velde, P. (2020). COVID-19 and food security: Gendered dimensions. Policy note of the World Bank. Retrieved 10.07.2020. https://elibrary.worldbank.org/doi/abs/10.1596/33813 .

Nicola, M., Alsafi, Z., Sohrabi, C., Kerwan, A., Al-Jabir, A., Iosifidis C., Agha M., Agha R. (2020). The socio-economic implications of the coronavirus pandemic (COVID-19): A review. International Journal of Surgery. 78: 185-193.

O'Sullivan, M., Rao, A., Banerjee, R., Gulati, K., Vinez, M. (2014). Levelling the field: Improving opportunities for women farmers in Africa. Washington DC: World Bank Group. Retrieved 15.06.2020. http://documents 1.worldbank.org/curated/en/579161468007198488/pdf/860390WP0 WB0ON0osure0date0March0180.pdf.

Otache, I. (2020). The effects of the Covid-19 Pandemic on the Nigeria's economy and possible coping strategies. Asian Journal of Social Sciences and Management Studies, 7(3), 173179. DOI: 10.20448/journal.500.2020.73.173.179.

OXFAM (2020). Oxfam International press release on COVID-19. Retrieved 10.07.2020. https://www.oxfam.org/en/press-releases/12000-people-day-could-die-covid-19linked-hunger-end-year-potentially-more-disease 
Phillipson, J., Gorton, M., Turner, R., Shucksmith, M. et al. (2020). The COVID-19 pandemic and its implications for rural economies. Sustainability, 12(10), 3973. DOI:10.3390/su12103973

Richards, TJ. \& Rickard, B. (2020). COVID-19 impact on fruit and vegetable markets. Canadian Journal of Agricultural Economics (Special Issue), 68, 189-194. https://doi.org/10.1111/cjag.12231

Saha, T. \& Bhattacharya, S. (2020). Consequence of lockdown amid COVID-19 pandemic on Indian agriculture. Food and Scientific Reports, 1 (Special Issue), 47-50.

Sekeroglu, N. \& Gezici, S. (2020). Coronavirus pandemic and some Turkish medicinal plants. Anatolian Clinic Journal of Medical Sciences, 25 (1- Special Issue), 163-182.

Seleiman, M., Selim, S., Cezar, JF. et al. (2020). Will novel Coronavirus (COVID-19) pandemic impact agriculture, food security and animal sectors? Bosicence Journal, 36(4), 1315-1326. DOI: 10.14393/BJ-v36n4a2020-54560

Stephens, EC., Martin, G., Van Vijk, M., Timsina, J., Snow, V. (2020). Impacts of COVID-19 on agricultural and food systems worldwide and on progress to the sustainable $\begin{array}{lllll}\text { development } \quad \text { goals. } & \text { Agricultural } & \text { Systems, } & 183,\end{array}$ https://doi.org/10.1016/j.agsy.2020.102873

Toktas, Y. (2020). Food sector in Turkey during COVID-19 pandemic. Current Researches in Economics and Administrative Sciences. ISBN: 978-9949-46-025-9. 1st ed. Pp: 623640.

Zhang, X. (2020). Chinese livestock farms struggle under COVID-19 restrictions. International Food Policy Research Institute. Retrieved 20.06.2020.https://www.ifpri.org/blog/chinese-livestock-farms-struggle-under-covid19-restrictions

Zirh, BC., Karakilic, IZ., Cetinkaya, O., Ayaes, S., Ozsoy, A., Karabiyik, E. (2020). Korona virüs salgınının mevsimlik gezici tarım işçileri ve onların çocukları ile bitkisel üretime olas1 etkisi (Potential impact of Corona Virus pandemic on seasonal temporary agricultural labourers, their children and hotricultural production). Report of ILO Turkey, pp: 150. Retrieved 10.06.2020 https:/www.ilo.org/wcmsp5/groups/public/--europe/---ro-geneva/---ilo ankara/documents/publication/wcms_743368.pdf

Zurayk, R. (2020). Pandemic and food security: A view from the Global South. Journal of Agriculture, Food Systems, and Community Development, 9(3), 17-21. https://doi.org/10.5304/jafscd.2020.093.014 